\title{
CIDADES SUSTENTÁVEIS: CENAS ETNOGRÁFICAS SOBRE EXPERIÊNCIAS AUTÔNOMAS DE ECONOMIA CIRCULAR
}

\author{
Caroline Soares de Almeida ${ }^{1}$
}

\section{Introdução ${ }^{2}$}

Diante do desafio global de estabelecer diretrizes que privilegiem o desenvolvimento sustentável, a Organização das Nações Unidas criou, em 2015, uma agenda socioambiental que prevê dezessete Objetivos de Desenvolvimento Sustentável ${ }^{3}$ (ODS), os quais determinam que "cada país desfrute de um crescimento econômico sustentado, inclusivo e sustentável e de trabalho decente para todos". Todos os países que fazem parte da ONU foram signatários desse acordo internacional, comprometendose a criar políticas que minimizem os danos ao meio ambiente até 2030. No entanto, passados cinco anos, fica claro que grande parte desses países está distante do cumprimento das metas pré-estabelecidas. Se por um lado a Comissão Europeia anunciou, no final de 2019, a implantação do European Green Deal - um plano estratégico de crescimento que pretende transformar todos os setores da economia, tais como transporte, indústria, energia, agricultura, construção civil, etc. - em todos os países membros da União Europeia, tornando a Europa o primeiro continente neutro, em termos climáticos, até $2050^{4}$. Por outro, o Brasil parece ter abandonado o já frágil planejamento lançado em $2017^{5}$ : segundo o Observatório do Clima o grande aumento no desmatamento em áreas da Floresta Amazônica no ano 2020, tornarão 29\% maior a

\footnotetext{
${ }^{1}$ Universidade Federal de Santa Catarina, Brasil. Email: almeidacarol@yahoo.com ORCID id: https://orcid.org/0000-0003-1361-6616

${ }^{2}$ Pesquisa financiada pelo Conselho Nacional de Desenvolvimento Científico e Tecnológico (CNPq) através da Bolsa de Extensão, sob a supervisão da Dra. Carmen Silvia Rial, e pela Coordenação de Aperfeiçoamento de Pessoal de Nível Superior (CAPES) através da Bolsa de Pós-Doutorado no Exterior pelo Programa CAPES/NUFFIC na Vrije Universiteit Amsterdam (VU - Amsterdam), coordenados por Dra. Carmen Silvia Rial e Dr. Freek Colombijn. Agradeço a todos colegas (da rede de pesquisadores em Antropologia do Lixo/Resíduos) que contribuíram para a construção das ideias contidas neste texto e discutidas em nossas reuniões quinzenais.

${ }^{3}$ ORGANIZAÇÃO DAS NAÇÕES UNIDAS. Transformando o nosso planeta: a agenda 2030 para um desenvolvimento sustentável.

Disponível em: https://nacoesunidas.org/wp-content/uploads/2015/10/agenda2030-pt-br.pdf

${ }^{4}$ Objetiva-se formular um conjunto de leis específico com vistas a implantação da Green Economy. Para mais, ver: European Green Deal.

Disponível em: https://ec.europa.eu/commission/presscorner/detail/e\%20n/ip 196691

Acesso em: 21 de maio de 2020.

${ }^{5}$ BRASIL/Comissão Nacional ODS. Plano de Ação 2017-2019. Disponível em: https://www.cnm.org.br/cms/images/stories/Links/19122017 Plano_Acao_ODS.pdf

Acesso em: 21 de maio de 2020.
}

Iluminuras, Porto Alegre, v. 21, n. 55, p. 104-126, dezembro, 2020. 
emissão de gases responsáveis pelo efeito estufa ${ }^{6}$. Aliás, entre negacionismos e alardes, os efeitos causados pela degradação ambiental dos últimos dois séculos nunca foram tão sentidos em diferentes locais do globo: invernos mais quentes; derretimentos de geleiras e de montanhas; extinção de espécies; aumento de catástrofes causadas por intempéries; entre outros.

A pandemia por COVID-19 também configura como reflexo do mal gerenciamento do planeta. Passamos por um momento bastante crítico. Estamos diante de uma crise financeira - de repente, a maior do que poderíamos chamar grosseiramente de "história mundial" - e no prenúncio do desabamento de estruturas institucionais seculares. Não por acaso, esse agravamento, talvez colapso, acontece ao mesmo tempo em que a face mais sombria do neoliberalismo atingiu seu ápice: “o Estado neoliberal assim se manifesta como Estado mínimo (em políticas de assistência social, em intervenção no mercado e no aparato produtivo) e forte (nas políticas repressivas)" (Viana, 2008:8). Conforme nos alerta Sherry Ortner $^{7}$ (2011), os momentos de desastres são os mais propícios ao crescimento de políticas neoliberais.

By the phrase "disaster capitalism" in her title, Klein means not only the general ways in which extreme free-market capitalism is an economic disaster for many people and countries, but the more specific fact that real disasters (the debt crisis of New York City in the 70s, the collapse of the Soviet Union in 1989, Hurricane Katrina in 2005) are explicitly seen as the best breeding grounds and opportunities to transform old economic regimes into neoliberal ones. A large part of "transforming old economic regimes" involves selling off state-operated properties, goods, and institutions to private buyers, and replacing those state operated entities with private, forprofit ones. In the wake of Hurricane Katrina, for example, the city of New Orleans was persuaded to sell virtually the entire public school system to private, for-profit operators. Discussing the New Orleans case as her opening example, Klein sets up the premise of the book: "I call these orchestrated raids on the public sphere in the wake of catastrophic events, combined with the treatment of disasters as exciting market opportunities, 'disaster capitalism' (Ortner, 2011)".

É neste último estágio do neoliberalismo que surge a necessidade de reconstrução das solidariedades sociais, "o que explica o renascimento do interesse pela religião e pela moralidade, por novas formas de associacionismo (em torno de questão de direitos e cidadania, por exemplo) e mesmo o retorno de antigas formas políticas (fascismo. nacionalismo, localismo e coisas do tipo)" - (Harvey, 2008: 91). Entende-se o neoliberalismo como uma etapa do capitalismo - pensado aqui como um processo. Uma

\footnotetext{
${ }^{6}$ Avanço no desmatamento deve levar o Brasil a ter aumento nas emissões mesmo com a paralisação de atividades na pandemia. Disponível em: https://g1.globo.com/natureza/noticia/2020/05/21/avanco-dodesmatamento-deve-levar-brasil-a-ter-aumento-nas-emissoes-mesmo-com-paralisacao-de-atividades-napandemia.ghtml. Acesso em: 21 de maio de 2020.

${ }_{7}^{7}$ Agradeço às queridas Jainara Oliveira e Chiara Albino pelas indicações de leitura.
} 
solução encontrada para por fim à crise gerada pelo regime de acumulador anterior, já saturado pela queda na taxa de lucro médio e pelas lutas de movimentos sociais (Viana, 2008). David Harvey define esse modelo de acumulação de capital como:

Neoliberalismo é em primeiro lugar uma teoria das práticas políticoeconômicas que propõe que o bem-estar humano pode ser melhor promovido liberando-se as liberdades e capacidades empreendedoras individuais no âmbito de uma estrutura institucional caracterizada por sólidos direitos a propriedade privada, livres mercados e livre comércio (Harvey, 2008: 12).

Desde 2018, quando iniciei o pós-doutoramento no Programa de Pós-Graduação Interdisciplinar em Ciências Humanas (PPGICH/UFSC), tenho pesquisado consumo e descarte de resíduos domésticos: primeiro pensando as formas de sensibilização a partir da Tecnologia Social (TS) de Gestão Comunitária de Resíduos Orgânicos desenvolvida na (Associação) Revolução dos Baldinhos; depois, com a aprovação do financiamento de uma avaliação dessa mesma TS pelo $\mathrm{CNPq}^{8}$, incluindo esse modelo nos Objetivos para o Desenvolvimento Sustentável da Agenda 2030 da ONU; e por último, comparando com outros modelos de gestão de resíduos independentes existentes na União Europeia durante o período em que estive como pesquisadora visitante no Department of Social and Cultural Anthropology da Vrije Universiteit Amsterdam. Posto isso, este artigo aborda três situações etnográficas diferentes: Revolução dos Baldinhos, em Florianópolis; Movimento Lixo Zero, em Portugal; e Taste Before You Waste, em Utrecht. Também incluo imagens produzidas por mim durante o trabalho de campo nessas localidades. Trata-se de observações iniciais colhidas durante o trabalho de campo nesses três enquadramentos, todos diretamente afetados por políticas neoliberais.

Intenta-se com isso discutir de que forma as pessoas, em contextos diversos, têm se organizado - em associações, movimentos, coletivos, etc. de resistência autônomas para minimizar os efeitos causados pela crise ambiental, dentro de diferentes projetos governamentais neoliberais e como essas ações de resistências que convergem para as metas assinaladas na Agenda 2030 da ONU. Como pano de fundo estão as mudanças nas estratégias dos governos locais ocorridas nos últimos anos: de políticas públicas voltadas para o "bem-estar social" e protecionismo de mercado interno, para políticas pautadas na segurança pública, altamente penalizantes (Wacquant, 2012), e na

\footnotetext{
${ }^{8}$ Através do edital CNPq/MCTIC/MDS. Corresponde ao projeto contemplado, "Avaliação de Tecnologia Social - O Programa Revolução dos Baldinhos e a replicação da gestão comunitária de resíduos orgânicos em comunidades de Florianópolis (SC) e Iranduba (AM)" - coordenado pela Dra. Carmen Silva Rial.
} 
economia de livre mercado. Contudo, não existe a pressuposição de que os desdobramentos do neoliberalismo se desenvolvam da mesma forma nesses locais. Ao contrário, ressalta-se que se trata de três campos diferentes, três modelos que incentivam a economia circular, com índices socioeconômicos distintos e lutas políticas próprias.

\section{Associação Revolução dos Baldinhos - Florianópolis/Brasil.}

O Projeto Revolução dos Baldinhos (hoje associação) teve início em outubro de 2008 na comunidade da Chico Mendes, situada no Bairro Monte Cristo, área continental de Florianópolis (SC). A implementação foi motivada pelos altos índices de infecção por leptospirose na região, consequência da infestação de ratos e da temporada de chuvas que acometiam o local. Moradores e funcionários do Centro de Saúde local debateram medidas que poderiam ser tomadas para impedir o descarte indevido dos rejeitos domésticos, "alimento para os ratos", muitas vezes depositados nas ruas e nos terrenos baldios. Desse contexto, surgiu a Revolução dos Baldinhos que, desde o início, contou com a assessoria do Centro de Estudos e Promoção da Agricultura de Grupo ${ }^{9}$ (CEPAGRO) e o apoio inicial para a coleta das bombonas da Autarquia de Melhoramentos da Capital $^{10}$ (COMCAP). Entre os objetivos da Revolução estavam: a gestão comunitária de resíduos orgânicos a partir da compostagem; o incentivo à agricultura urbana e à educação ambiental. A técnica introduzida provinha de pesquisas em agroecologia realizadas no CEPAGRO/UFSC (Abreu, 2013). O diferencial incorreu na forma de sensibilização dos moradores (Cruz; Bittencourt, 2019) e fez com que "a 'Revolução' se tornasse uma ideia ${ }^{11}$ ".

\footnotetext{
${ }^{9}$ Tal entidade está vinculada ao Centro de Ciências Agrárias da Universidade Federal de Santa Catarina.

${ }^{10} \mathrm{O}$ projeto, de início, conseguiu articular o apoio para a coleta das bombonas dos Pontos de Entrega Voluntária (PEVs) até o Pátio de Compostagem na Escola América Dutra Machado. Porém, essa parceria acabou em 2016 e, atualmente, a coleta é realizada em carrocinhas, puxadas pelos integrantes do PRB. O PRB continua realizando as pesagens diárias dos resíduos.

${ }^{11}$ A frase é repetida como um lema entre os participantes.
} 


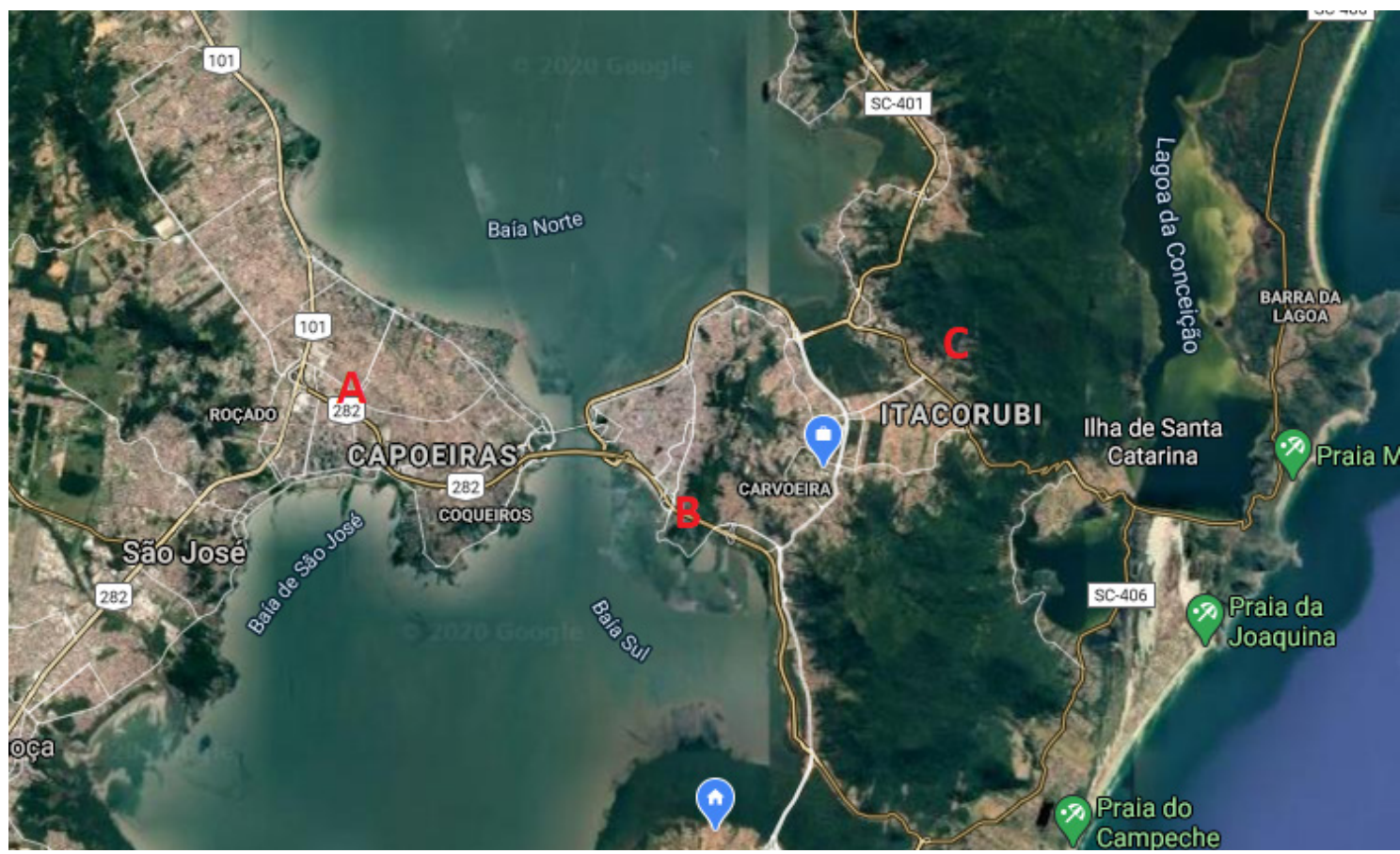

Figura 1 - Mapa da região central de Florianópolis (Continente e Ilha): A) Chico Mendes; B) Morro do Mocotó/Queimada; C) Morro do Quilombo (Google Maps).

Na Tecnologia Social ${ }^{12}$ (TS) desenvolvida pela Revolução dos Baldinhos, a sensibilização é realizada por integrantes que mantêm o diálogo com a comunidade. Busca-se, assim, identificar as demandas e compreender as lógicas e morais que permeiam as noções de afeto e solidariedade locais. A partir desse reconhecimento é que os integrantes introduzem a educação ambiental. As moradias participantes recebem um baldinho para armazenar o material orgânico descartado. O processo de coleta dos resíduos é realizado nos Pontos de Entrega Voluntária (PEVs) por membros da Revolução - que também são responsáveis pela reviragem, distribuição de hortas verticais e peneiragem da terra adubada dentro da ideia de Gestão Comunitária de Resíduos (Abreu, 2013; Cruz; Bittencourt, 2019). Ao final desse processo, o adubo é distribuído entre os moradores e, o excedente, fica disponível à venda - o que gera parte da renda do projeto.

${ }^{12}$ Em 2011, a Revolução dos Baldinhos ganhou a certificação de Tecnologia Social pela Fundação Banco do Brasil. 


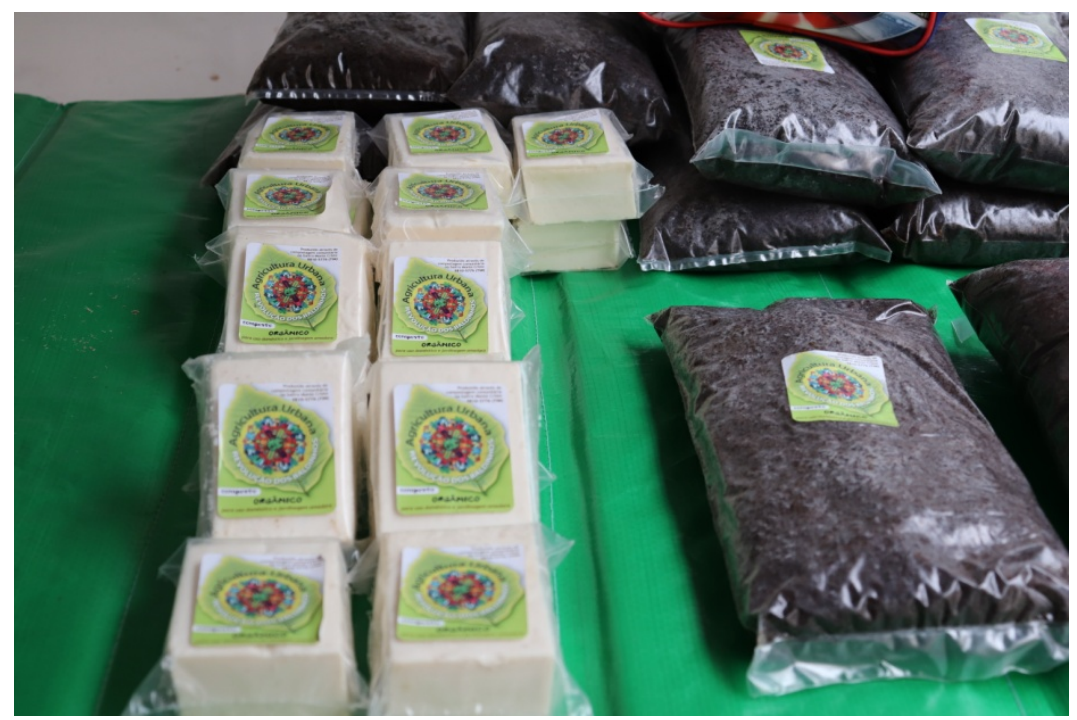

Imagem 2 - Sabão e adubo: produtos da Revolução produzidos a partir do descarte de resíduos domésticos

A ideia principal da Revolução dos Baldinhos consiste na economia circular do alimento através da solidariedade/sensibilização (Singer, 2002), tendo em vista a quebra com a cadeia linear de produção e o foco na eliminação do desperdício e da desnutrição, além da diminuição do envio de resíduos para o aterro sanitário ${ }^{13}$.

A cena que se apresenta aconteceu em uma das formações populares em Gestão Comunitária de Resíduos Orgânicos, uma parceria entre o Instituto Çarakura e a Revolução dos Baldinhos com o financiamento da Emenda Parlamentar que instituiu a "Rede Municipal de Gestão Comunitária de Resíduos Orgânicos e Agricultura Urbana"14 durante o ano de 2019. Ao todo, foram três "replicações" dessa TS, distribuídas em comunidades localizadas nos morros da capital: Mariquinha, Queimada/Mocotó e Quilombo. Neste formato, a replicação da metodologia acontece em duas etapas. A primeira consiste na formação popular em gestão de resíduos orgânicos e agricultura urbana, em que moradores da comunidade escolhida participam de uma oficina técnica e do planejamento da ação. Na etapa seguinte, são realizados o mutirão de limpeza da área, o plantio de canteiros e a construção das primeiras leiras.

\footnotetext{
${ }^{13}$ Salienta-se que, a cada semana, são compostados em torno de 1,5 toneladas de resíduos.

14 Financiamento incluído na Lei Orçamentária Anual N.10.321 de 2017 da Prefeitura Municipal de Florianópolis, por indicação do Vereador Marcos José de Abreu - o Marquito.
} 

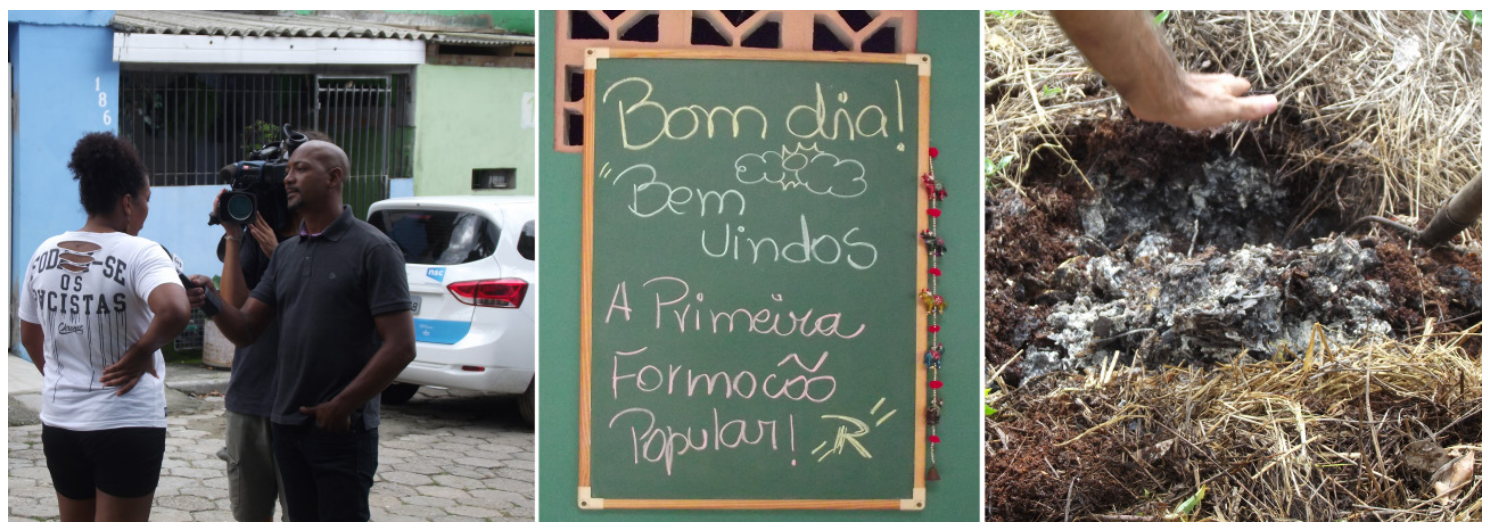

Imagem 3 - Formações em Gestão Comunitária de Resíduos Orgânicos

Este relato aconteceu no Morro da Queimada/Mocotó, na região do maciço do

Morro da Cruz, área central de Florianópolis, do dia 24 de março de 2019:

Descansávamos após o almoço coletivo, um banquete de massas e molhos gentilmente preparado por membros do Movimento Slow Food ${ }^{15}$. O Convivium Slow Food Mata Atlântica é um parceiro antigo da Revolução dos Baldinhos, organizando os eventos Disco Xepa ${ }^{16}$. O local escolhido, tanto para a formação quanto para a construção das leiras, localizava-se junto a um centro comunitário no limite entre as comunidades da Queimada e do Mocotó - situado no alto da única via de acesso de veículos ao local. De acordo com esse formato, a formação comunitária acontecia durante um fim de semana. Aproveitávamos a vista que se tem da Baia Sul e de partes do Sul da Ilha e continente. Uma caixa de som tocava músicas no estilo rap e aproveitávamos a conversa para nos conhecer melhor. Cintia estava conosco e aproveitava para relaxar um pouco antes de iniciar o próximo estágio da oficina. Em um determinado momento, duas pessoas começam uma discussão. Tratava-se de uma mãe que acusava um homem de destratar um de seus filhos. Algumas pessoas ao redor tentavam apaziguar a situação. Com o tempo, acabamos nos envolvendo novamente nas atividades para a construção dos canteiros de compostagem e da horta. Não demorou muito para que alguns carros da Polícia Militar e do Batalhão de Operações Policiais Especiais subissem fechando as saídas da comunidade, ao mesmo tempo em que os policiais se espalhavam pelas travessas empunhando armas entre moradores. Lembro-me do choque ao presenciar essa cena tão descabida, tanto pelo sobressalto causado pela invasão repentina quanto pela violência policial que ostentava armamento pesado entre crianças que brincavam por todos os lados. Fomos orientadas por Cíntia a continuar a construção das leiras sob a supervisão da Cíntia, coordenação da Associação Revolução dos Baldinhos. De repente um burburinho tomou conta das ruas: policiais haviam algemado um dos moradores e o encaminhava uma das viaturas. Aos pouco o cerco foi se desfazendo. Uma pequena multidão se formou em frente ao centro comunitário, algumas pessoas protestavam diante da Unidade de Polícia instalada próxima ao local em que estávamos.

\footnotetext{
${ }^{15}$ Movimento nascido na década de 1980 como crítica ao Fast Food. Tem como bandeira, o rompimento com a larga cadeia de produção industrial do alimento em prol do preparo caseiro das refeições a partir de produtos orgânicos advindos diretamente da terra, dentro do que consideram "bom, limpo e justo" (Schneider, 2015).

${ }^{16}$ Evento realizado pelo Movimento Slow-Food, tendo sua primeira edição na Alemanha (2012), com o nome Schnippel Disko, em que houve a preparação coletiva de alimentos que seriam descartados pelo comércio e a distribuição gratuita dessas refeições (Schneider, 2015). No entanto, o Convivium Mata Atlântica, através da iniciativa do Chef Philipe Bellettini, adaptou o formato para as periferias de Florianópolis: além do banquete, há oficinas e apresentações de DJs e rappers das comunidades.
} 
Perguntei a R. ${ }^{17}$, um dos moradores que vinha da rua, o que havia acontecido. A informação que ele tinha era que uma senhora havia reclamado de um dos participantes do mutirão, seu conhecido, aos agentes da Unidade de Polícia e que esses agentes haviam pedido reforços para "conter" a situação. Tratavase do mesmo caso que havíamos acompanhado logo após o almoço, mas o morador detido pela polícia não tinha nada a ver. A narrativa de R. apontava para uma grande injustiça, já que os policiais prenderam um trabalhador. Também garantiu que o homem havia sofrido violência física. Assim que as viaturas policiais deixaram o local, os responsáveis pela organização da formação encerraram as atividades. R. lamentou o ocorrido ao mesmo tempo em que nos alertava para a violência policial comum ao cotidiano da comunidade. Fala prontamente completada por Cíntia: "assim vocês têm noção da realidade vivida na periferia". Nosso grupo deixou o local em um automóvel. Na semana que segui, os moradores dos Morros do Mocotó fecharam uma das avenidas que levam ao centro da cidade, nas imediações da comunidade em manifestação contra a violência do estado e a prisão do morador $^{18}$.

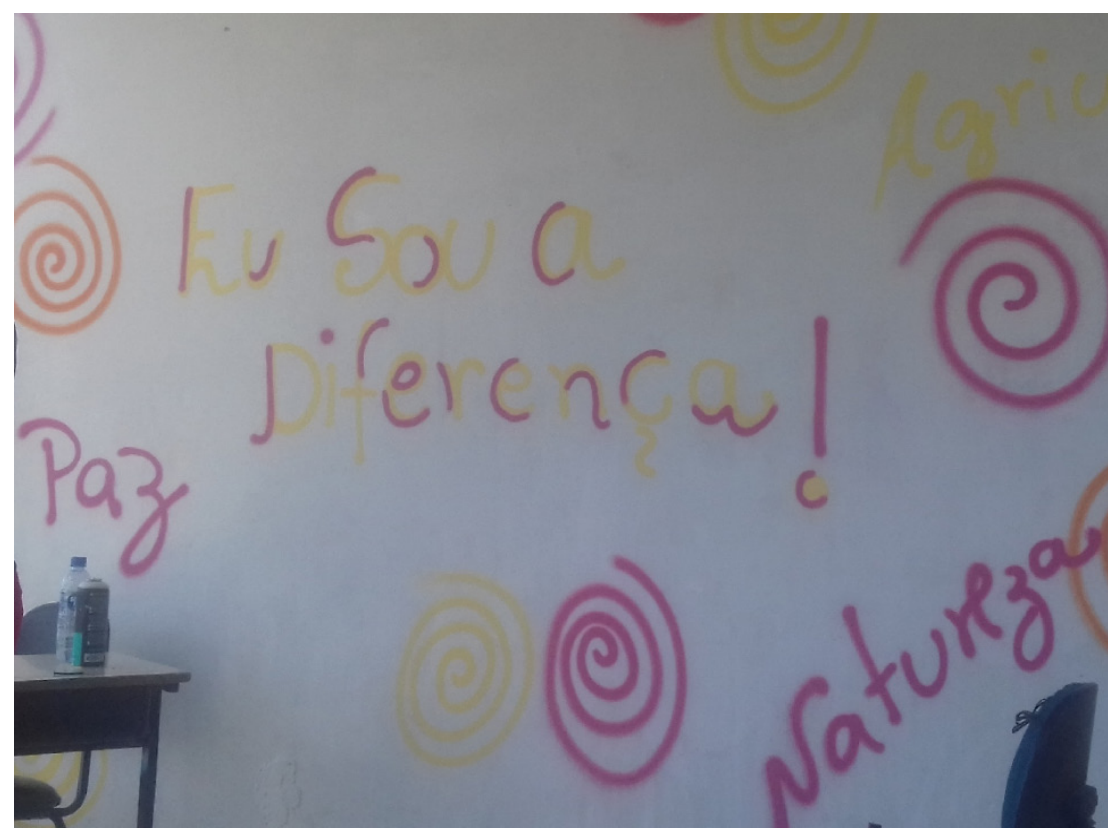

Imagem 4- Painel grafitado por Cíntia durante a formação no Morro da Queimada/Mocotó

\section{Movimento Lixo Zero Portugal}

Tive contato com o Movimento Lixo Zero ainda em Florianópolis, a partir de um evento organizado na Universidade Federal de Santa Catarina em outubro de 2018. Uma das palestrantes citou a relação com outras frentes desse movimento em diversos países, entre eles, em Portugal. Como já possuía certa familiaridade com o país, afinal permaneci alguns meses em "doutorado sanduíche” no Instituto de Ciência Sociais

\footnotetext{
${ }^{17}$ Chamo de "R." um de meus interlocutores dessa comunidade. O nome foi alterado para preservar seu anonimato já que não possuo sua autorização formal.

${ }^{18}$ Trecho extraído de diário de campo.
} 
(Universidade de Lisboa), fiquei interessada em conhecer mais sobre as características do movimento no país. Encontrei duas frentes diferentes: a Zero Waste PT e a Lixo Zero Portugal.

Situado na Travessa Lagares, no bairro da Moraria, em Lisboa, encontra-se o escritório do Zero Waste PT. O espaço foi fornecido pela Câmara Municipal de Lisboa através do programa operacional regional Por Lisboa/Bairros - Rede de Desenvolvimento Local. O prédio foi inaugurado em maio de 2015 com o objetivo de restaurar e refuncionalizar o quarteirão dos Lagares, área com construções prépombalinas, para a criação do Centro de Inovação da Mouraria, Mouraria Creative Hub - financiado com verba do Fundo Europeu de Desenvolvimento Regional. Conforme descrição oficial, o Centro é a primeira incubadora da cidade que apoia projetos de "indústrias criativas". Ao todo são treze iniciativas, entre elas o Zero Waste Lab. O movimento em Lisboa tem por objetivo a mobilização social para a mudança no comportamento, tendo como foco principal a criação e gestão dos resíduos. O manifesto ${ }^{19}$ criado pelo Zero Waste Lab consiste em três passos: $1^{\circ}$ entender o sistema e projetar a intenção; $2^{\circ}$ assumir o compromisso e a mudança; $3^{\circ}$ juntar-se a uma rede zero desperdício. Assim, a iniciativa aglomera uma vasta rede de organizações, movimentos e empresas que compartilham da mesma preocupação com a sustentabilidade, além de reunir projetos que procuram diminuir/eliminar resíduos como: "Academia Lixo Zero", focada na educação ambiental através de palestras e workshops em escolas, centros comunitários, etc; "Beata é plástico": alerta para o descarte indevido de "beatas" de cigarro (bitucas de cigarro); "Lixo Zero Mouraria", projeto pensado junto à comunidade de Mouraria - e com a Câmara Municipal de Lisboa - para pensar soluções Lixo Zero.

Durante uma de minhas visitas, realizada durante o primeiro dia útil do ano de 2020, as ruas ao redor do Centro de Inovação da Mouraria estavam cobertas de lixo: no chão, pontas de cigarros se misturavam a papéis coloridos, utilizados tradicionalmente em comemoração pela passagem de ano; as lixeiras, por outro lado, estavam cheias com resíduos diversos. O bairro, em si, é bastante visado por turistas jovens, já que está bastante próximo ao centro e guarda boa quantidade de bares e cafés. Com as festas de final de ano, a cidade de Lisboa estava lotada. Nos últimos anos, com o crescimento deste setor em Portugal (o país está cinco anos no topo da lista de melhor destino

\footnotetext{
${ }^{19}$ Para mais, visitar: https://www.zerowastelab.pt/home.php
} 
turístico), houve também a proliferação de apartamentos para locação em curta estadia. Neles, na maioria das vezes, inexistem informações sobre como deve ser procedido o descarte do lixo na cidade. Dessa forma, as pessoas, na condição de visitante, não se comprometem com esses cuidados.
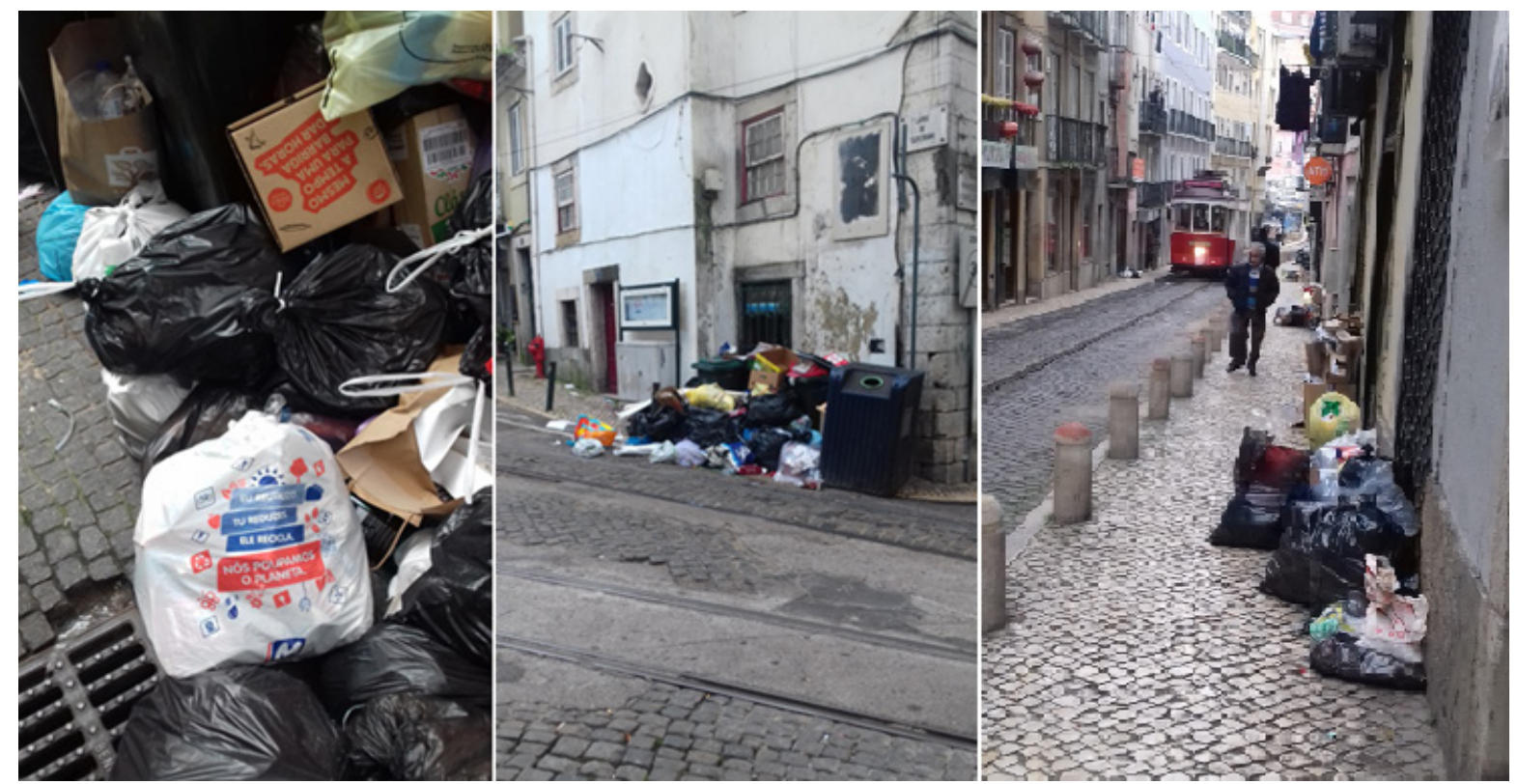

Imagem 5- Ruas do bairro de Mouraria (01/01/2020)

O Movimento Lixo Zero Portugal foi desenvolvido por Ana Milhazes ${ }^{20}$ na tentativa de alertar as pessoas para o consumo consciente, disseminando informações e dicas que auxiliem as pessoas interessadas na mudança dos modos de vida - voltado para uma perspectiva minimalista. Em poucas palavras, o minimalismo contemporâneo consiste em um estilo de vida que tem como principal meta a drástica diminuição no acúmulo de bens de consumo. Havia lido algo a respeito do trabalho desenvolvido por Ana e, assim que tive a confirmação do pós-doutorado na Vrije Universiteit Amsterdam, planejei ir até o país ibérico. A cena que descrevo a seguir corresponde a uma entrevista concedida pela ativista em dezembro de 2019:

Logo de início, Ana deixou claro que se trata de um movimento, não possui
caráter organizacional ou institucional. Disse que sempre se preocupou com a
separação do lixo, mas em 2011, após um período de grandes
questionamentos na sua vida, teve a necessidade de seguir um estilo de vida
minimalista, desapegando de aspectos materiais e produzindo o mínimo de
resíduos. O clic veio após descobrir o minimalismo. O primeiro passo foi
criar o blog Ana Go Slowly (2011), em que passou a escrever sobre suas
experiências com o minimalismo e a dar dicas sobre a redução de resíduos no
cotidiano. Em 2016, após ler o livro de Bea Johnson ${ }^{21}$, fundou o Movimento

${ }^{20}$ Ativista fundadora do moviemento Lixo Zero Portugal.

${ }^{21}$ Desperdício Zero: simplifique a sua vida reduzindo o desperdício em casa. Bea Johnson é de origem francesa e vive nos Estados Unidos com sua família, onde fundou o Zero Waste Home Movement. 
Lixo Zero Portugal. O movimento passou a ser divulgado por um blog oficial - Lixo Zero Portugal - e em um grupo no Facebook, construído para dividir experiências e dicas sobre consumo consciente: "achei que não haveria ninguém, mas tive adesão". Ana entrou em contato com diferentes empresas e lojas de todo o país a fim de recolher informações sobre produtos/vendas que incorporassem o conceito minimalista: "contactava lojas de todo o país a perguntar se havia produtos a granel e se poderia levar meus próprios sacos; [...] não precisava ser inteiro [a loja] a granel". Assim listava quais lojas forneciam a opção e quais produtos eram vendidos a granel. Uma programadora do grupo criou a página www.agranel.pt, que reuniu os locais em que serviços de vendas a granel podem ser encontrados em Portugal. Depois, Ana passou a ser convidada a ministrar palestras e workshops sobre a experiência de vida minimalista e redução de resíduos. Desde 2017, após um período em que esteve bastante doente, resolveu deixar seu emprego e levar uma vida mais tranquila. Começou a dar aulas de Ioga e manteve a agenda de palestras: "eu faço minhas palestras para pessoas que estão interessadas. [...] levo meu kit lixo zero e inicio falando sobre ele". A ativista ${ }^{22}$, como reforça em sua fala, diz que de uma forma geral, as pessoas têm a noção de que produzem muito lixo, sabem que é um problema, mas não sabem o que fazer para reduzir. Assim, os primeiros workshops tratam de questões bem básicas. Procura sempre ressaltar que não se deve forçar uma pessoa - os familiares, amigos, colegas - a ser Lixo Zero, pois isso traz antipatia à causa. Em suas falas, destaca: "foquem em vocês, façam vocês, e as pessoas vão perceber que é possível". Sobre a sensibilização (em Portugal) para a aquisição de hábitos sustentáveis, Ana afirma que nos últimos anos tem crescido. Destaca a importância da comunicação social em colocar a temática nas pautas diárias, bem como do movimento de greves estudantis, iniciado por Greta Thunberg, que tem pressionado os governos e o parlamento europeu, pedindo ações imediatas contra o aquecimento global e a poluição. Mas faz um alerta sobre essas manifestações: "a realidade é um bocadinho distante". Isso porque muitos jovens "não ligam a manifestação ao hábito": "não é só governo que tem que agir". Segundo a fundadora do movimento Lixo Zero Portugal, entre os jovens há um "disfarçamento da realidade", pois não levam para a vida pessoal o que exigem do governo: "vi muitas pessoas durante as manifestações a jogar beatas de cigarro no chão". Com relação a governo, afirma que, de modo geral, Portugal procura alinhar-se às determinações de outros países da União Europeia. Estimulam os governos locais e as freguesias a criar ações de incentivo a práticas sustentáveis (compostagem, hortas comunitárias, Eco Fashion, etc). Entretanto, as ações não atingem necessariamente a diminuição do consumo - o cerne do grande problema na produção de resíduos: "mas nunca vai ser lixo zero, [porque] o minimalismo não é interessante para a economia".

\section{Coletivo Taste Before You Waste - Utrecht/Países Baixos}

A iniciativa surgiu em Amsterdã, em 2012, no intuito de diminuir os resíduos orgânicos através do reaproveitamento de alimentos que seriam descartados no lixo. O TBYW atua em três frentes de reinserção desses alimentos: em mercados circulares, no preparo de refeições e em serviços de catering. Segundo um de seus coordenadores, o grupo de Utrecht só tem o nome em comum com a base em Amsterdam, já que é fortemente influenciada por perspectivas que procuram romper com o sistema

${ }^{22}$ Para ela, as palestras, workshops e administração do blog não trazem o fardo do trabalho porque se considera uma ativista o tempo todo. 
capitalista, diminuindo - ou mesmo - eliminando a troca monetária e privilegiando a prática de freeganismo. Além disso, a maioria das pessoas que atuam no coletivo são estudantes da Universidade de Utrecht e/ou são membros do ACU (Politiek Cultureel Centrum), um centro cultural anarquista.

As atividades do coletivo estão divididas em reuniões de planejamento, coleta dos alimentos e os jantares. As reuniões e os jantares acontecem na sede do ACU: um prédio de dois andares, onde no segundo encontram-se a cozinha, um depósito e uma biblioteca; no térreo estão um café e uma área para eventos (com um palco). Para a coleta dos alimentos é necessário ter bicicleta com uma grande cesta. Assim como acontece no Disco Xepa, grande parte dos alimentos é doada por comércios parceiros, entre aqueles que não estariam disponíveis para a venda. A outra parte advém do descarte de mercados, armazéns, quitandas, etc. Nesse caso, segundo o relato de um dos membros do grupo, precisa ter nacionalidade holandesa ${ }^{23}$. As estratégias de coletas são decididas nas reuniões de planejamento.
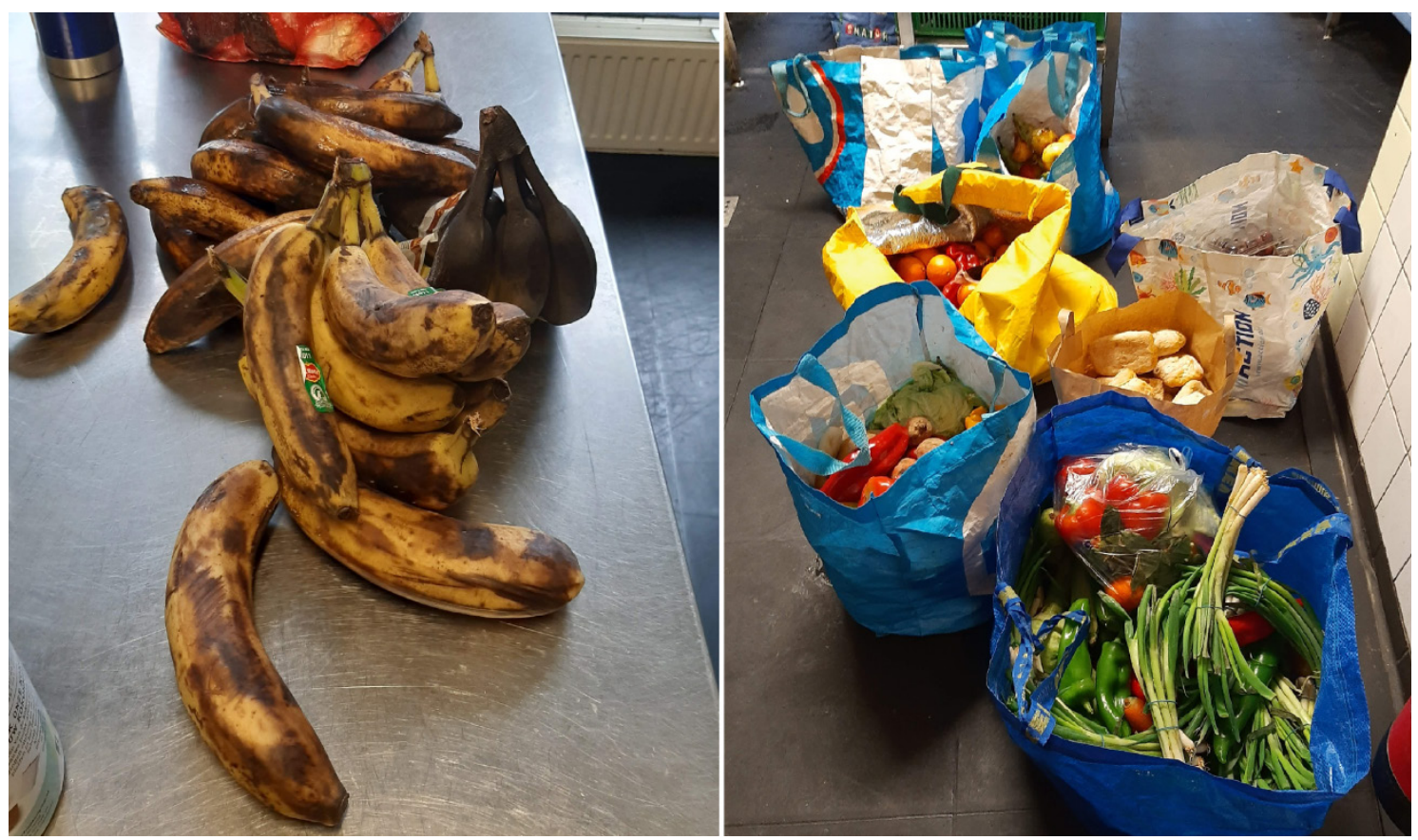

Imagem 6 - Alimentos captados/doados

Os jantares representam o grande momento e são organizados da seguinte forma: preparo e jantar propriamente dito. O preparo tem inicio no começo da tarde, quando os voluntários se reúnem na cozinha da sede. Os alimentos ficam a disposição das pessoas que irão cozinhar. Os pratos não são pré-definidos, assim qualquer pessoa tem a

\footnotetext{
${ }^{23} \mathrm{O}$ interlocutor, um brasileiro estudante da UU, afirmou que é um pouco perigoso se um estrangeiro for surpreendido pela polícia nessas ações.
} 
autonomia na escolha e na forma de fazer. A única exigência é que sejam pratos veganos, pois, como me explicou um dos interlocutores, "qualquer pessoa pode comer". Durante o preparo, os cozinheiros trocam dicas e conselhos no manejo dos alimentos. Em torno das $19 \mathrm{hrs}$, o menu é apresentado aos consumidores e é solicitada, aos que podem, uma colaboração em dinheiro. O meal é disponibilizado em forma de Buffet. As refeições são abertas a qualquer pessoa que queira participar e acontecem no café e no espaço para shows, tendo algumas vezes apresentações culturais e bazares de troca de roupas e de objetos. O serviço do bar também é realizado por voluntários, tendo cada um direito a uma cerveja.

A última cena refere-se a uma experiência de voluntariado em um dos jantares promovidos pelo TBYW:

Cheguei ao segundo andar do prédio da ACU um pouquinho depois das duas horas da tarde. O prédio ficava em Voorstraat, área central de Utrecht. O caminho da estação central era curto, resolvi fazer a pé apesar do vento forte e do frio que fazia naquela tarde. Sentados a mesa, numa espécie de antessala, estavam B., J. e mais uma mulher que ainda não conhecia. Almoçavam naquele momento, dividindo uma salada de folhas verdes e batatas. Cumprimentei cada um e me apresentei a terceira pessoal. Convidaram-me a comer com eles. Agradeci a gentileza e perguntei se poderia aquecer água para o chimarrão. Gosto de levar a cuia comigo para o campo, sempre surte diálogos iniciais. Mesmo sendo todos holandeses, falavam em inglês entre eles. Quando me aproximei iniciamos uma conversa sobre o chimarrão. Perguntaram o que era. Ofereci uma prova, mas ninguém quis experimentar. Aos poucos, outras pessoas foram chegando. Alguns eram estrangeiros, mas todos frequentavam (em diferentes níveis) - ou eram amigos de - a Universidade de Utrecht. A maioria era bastante jovem, eles variavam entre vinte e trinta anos e, possivelmente, eu era uma das pessoas mais velhas ali. Com um bom número de pessoas, começaram as movimentações para o preparo dos alimentos. Entre as/os voluntárias/os haviam os que atuavam diretamente no coletivo, mas também uma boa quantidade de "novatos" - estes, de acordo com B. tinham uma grande rotatividade. Uma dessas pessoas era C., inglesa que morava há poucos meses nos Países Baixos. Era formada em química e trabalhava em uma empresa no país para ficar mais perto do noivo. C. era uma das mais entusiasmadas.

A cozinha era bastante espaçosa: duas bancadas no centro; fogão; forno; duas pias; máquinas que escaldavam a louça; armários; freezer; mais bancadas. Tudo industrial. O chão estava repleto de sacolas com os produtos que seriam usados naquela noite. Perguntei ao B. como poderia ajudar. Ele me disse que poderia escolher um prato para fazer ou auxiliar alguém, mas que as pessoas tinham a liberdade para trabalhar como quisessem. Fiquei uns minutos um pouco confusa, sem saber bem o que fazer. Olhei um pouco o que tinha nas sacolas, basicamente produtos de feira. Eu gosto de cozinhar, mas fazer comida para muitas pessoas é algo que me assusta bastante. Pensei em fazer salada de fruta, já que não teria muito erro. Seria só picar uma boa variedade de frutas e espremer alguma coisa cítrica para fazer caldo. Éramos em torno de quinze pessoas. Peguei algumas frutas e me instalei em uma pia perto da janela. De tempos em tempos, vinha alguém perguntar o que eu estava fazendo e trocar sugestões sobre os pratos. Notei que esse momento, o de interagir nas decisões sobre o preparo do alimento consistia em uma parte bastante importante do processo. Um momento em que as pessoas se 
escutavam e procuravam se conhecer. Mesmo não havendo um menu prévio, o que é bastante comum em atividades semelhantes no meu trabalho de campo no Brasil ${ }^{24}$, existia uma certa harmonização entre os pratos. A única exigência é que sejam veganos. Segundo B., assim ninguém se sente excluído. Após o preparo, a comida é enviada ao café, estabelecimento que fica no térreo do prédio, em um elevador de alimentos. Os pratos para os voluntários são preparados, anteriormente, e também descem para a confraternização geral - cada voluntário também tem direito a uma cerveja para acompanhar a refeição. Enquanto jantávamos conversei um pouco com M., um brasileiro de Recife, mestrando em Gender Studies, que me contou um pouco sobre as ações para o recolhimento de alimento. Embora jovem, morava há algum tempo na Europa. A graduação em Filosofia foi realizada na Alemanha e a mãe era pós-doutoranda em Portugal. Voltou ao Brasil apenas para visitar o pai e o avô, mas iria realizar o trabalho de campo no país. Apresentou-me L., holandesa que havia realizado intercâmbio durante a graduação no curso de Ciências Sociais da UFSC. A certa altura, um dos membros do coletivo avisou que estava na hora de subirmos para limpar a cozinha. Essa hora assemelha-se bastante a uma confraternização, já que não há mais a obrigação do preparo dos pratos e do horário do jantar. Há muita música e, em alguns momentos, todos cantam juntos: o que aconteceu quando a playlist tocou "Take on $m e$ ", da banda A-Ha, que todos que estavam ali conheciam ${ }^{25}$.
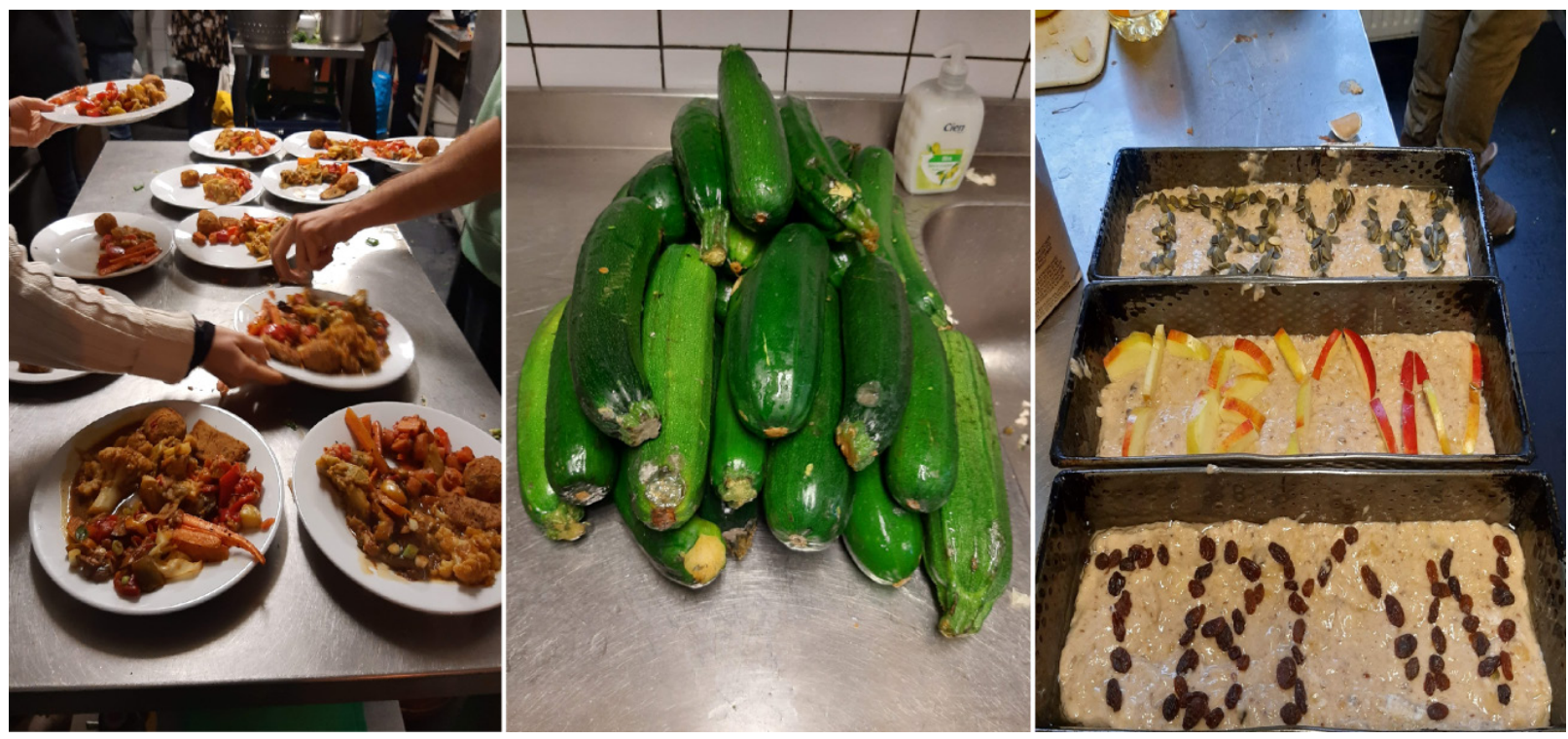

Imagem 7 - Voluntários preparando o jantar para o TBYW (Utrecht/Países Baixos, 2020)

\section{Campos, personagens e resistências}

Apesar da forte campanha de negacionistas ${ }^{26}$ que tentam dissipar o debate, é quase consenso entre órgãos ambientalistas e estudiosos na área que o desenrolar das

\footnotetext{
${ }^{24}$ Nas edições do Disco Xepa que participei como voluntária, os pratos são escolhidos por chefes de cozinha vinculados ao Movimento Slow Food.

${ }^{25}$ Trecho extraído do diário de campo.

${ }^{26}$ Refiro-me às teorias/ideologias que negam evidências científicas sobre o aquecimento global (climate change denial), que tratam do assunto como uma "hipótese", e que estão ligadas a governos
} 
políticas neoliberais em diferentes países, nos últimos anos, têm afetado a degradação do meio ambiente em diversas frentes - e alavancado as desigualdades sociais. Conforme nos apontaram os relatos apresentados neste artigo, os efeitos são sentidos de formas diferenciadas em todas as partes do mundo (Harvey, 2008), assim como em todas as camadas sociais. Essas três iniciativas também revelaram formas de resistência às dificuldades impostas, seja pela privação de alimentos saudáveis (ou mesmo de alimentos em geral), como no Taste Before You Waste; seja pela contaminação dos solos, das águas e do ar, resultantes do processo de produção de materiais e do descarte de resíduos, no caso do Lixo Zero Portugal; ou mesmo por esses dois fatores somados à forte repressão do Estado, como acontece no contexto da Revolução dos Baldinhos.

Este processo todo também faz aumentar a resistência. A partir da segunda metade da década de 1990, há um ressurgimento de uma negação do capitalismo, ainda incipiente, mas que vai crescendo paulatinamente (anarquismo, movimentos sociais, etc.). Este processo de fortalecimento do movimento de contestação vai ser realizado com contradições, mas expressando justamente uma resposta ao processo de aumento geral da exploração e tudo que é derivado daí (Viana, 2008: 8).

Nas narrativas, B., Ana e Cíntia surgem como personagens atuantes que utilizam estratégias diferenciadas em lutas localizadas contra o neoliberalismo. No primeiro, as ações do coletivo Taste Before You Waste de Utrecht ${ }^{27}$ procuram romper com a cadeia produtiva, subvertendo a lógica neoliberal, já que procura suprimir a valorização monetária em relação ao alimento. Todo produto utilizado na preparação dos pratos provem de mercadorias impróprias para a venda, seja pela validade ou pela aparência danificada (no caso dos vegetais). A ideia consiste em diminuir os resíduos ao mesmo tempo em que se mostra que o que se descarta poderia servir de alimento a muitas pessoas. Também constitui uma forte crítica ao sistema de acumulação atual, já que se estima que $30 \%$ de todo o alimento produzido no mundo é descartado ${ }^{28}$ antes de chegar ao consumidor, um número muito alto se pararmos para pensar no problema da fome que acomete quantidade bastante significativa da população. Embora a grande maioria das pessoas com quem tive contato pertencesse ao círculo da Universidade de Utrecht -

conservadores de (extrema) direita. Ver: Hansson, Sven. Science denial as a form of pseudoscience. Studies in History and Philosophy of Science. V. 63, jun. 2017, p. 39-47.

${ }^{27}$ Torna-se importante salientar que o TBYW de Utrecht não segue o padrão das demais frentes, as ações estão mais restritas aos jantares comunidades e às distribuições de alimentos recolhidos. As contribuições recolhidas durante os jantares comunitários são espontâneas.

${ }^{28}$ Os números são do Programa Mundial de Alimentos da ONU. Segundo a organismo, o desperdício de alimentos custa quase US\$ 1 trilhão anual à economia mundial, o que poderia erradicar a fome no mundo. Para mais, ver: Desperdício de comida custa quase US\$ 1 trilhão por ano em todo o mundo. Disponível em: https://news.un.org/pt/story/2019/10/1689492. Acesso em 22 de julho de 2020. 
e, apesar dos Países Baixos estarem entre os dez países com maior IDH no mundo ${ }^{29}$-, os jantares comunitários são abertos a qualquer pessoa.

A terceira narrativa trata de um movimento global, conhecido como Zero Waste Home, fundado por Bea Johnson em 2008, cujo objetivo consiste na mudança no estilo de vida - de forte influência minimalista - e na redução de resíduos domésticos. Para o sociólogo Erin Murphy (2018), o minimalismo contemporâneo, caracterizado pelo autor como "decluttering minimalism", incorpora de maneira involuntária a mentalidade neoliberal em seu esforço por desafiar o consumismo, definidor de sociedades pósindustriais. Procuro pensar movimentos minimalistas como o Zero Waste em uma perspectiva dialética em que o modelo adotado utiliza dos mesmos mecanismos sociais de mercado como um instrumento de resistência. Se, por um lado, procuram romper com a produção industrial de mercadorias físicas de grande potencial residual, por outro incentivam o consumo no setor de serviços ${ }^{30}$ e na venda de mercadorias "lixo zero". A página do movimento português, semelhante ao que acontece em outras partes do mundo, também funciona como uma espécie de catálogo de lojas e serviços, cujos princípios são o desenvolvimento sustentável através da redução drástica de resíduos. A maior adesão ainda é encontrada entre as camadas médias e altas, o que pode ser justificado pela valorização monetária que é atribuída aos produtos e oficinas/cursos (Murphy, 2018).

Existe uma grande preocupação com a produção e deposição de plástico, o que tem sido bastante debatido dentro da própria Comissão Europeia. Cerca de 60\% dos resíduos de plástico dos países do bloco provêm de embalagens ${ }^{31}$. Dados de 2014 apontam para a reciclagem de apenas $30 \%$ do total de plásticos descartados (Comissão Europeia, 2018:2). Diante disso, em 2018, o European Strategy for Plastics in a Circular Economy, primeiro plano adotado pela União Europeia, no intuito de diminuir a produção de plásticos e de fortalecer a indústria de reciclagem dos países membros através do incentivo à utilização de material plástico proveniente da reciclagem. Além

\footnotetext{
${ }^{29}$ De acordo com o Programa de Desenvolvimento da ONU (UNPD), publicado em 2018. Para mais, ver: Human Development Reports. Disponível em: http://hdr.undp.org/en/content/human-development-indexhdi. Acesso em 22 de julho de 2020.

${ }^{30}$ Em uma crônica escrita para a revista portuguesa Saber Viver, Ana incentiva um natal focado no convívio entre pessoas queridas e em menos material. A ativista ainda lembra àqueles que não quiserem abdicar de presentear, que existe uma grande quantidade de produtos que não geram resíduos, como ebooks e assinaturas de plataformas de entretenimento, além do setor de serviços, como cursos. Milhazes, Ana. Um natal mais simples e sem desperdícios. Revista Saber Viver.

Disponível em: https://www.saberviver.pt/bem-estar/natal-mais-simples-e-sem-desperdicio/

Acesso em 29 de agosto de 2020.

${ }^{31}$ Comissão Europeia.
} 
disso, entre as estratégias do European Green Deal está um imposto no valor de $€$ 0,80 sobre cada quilograma de plástico consumido que entrará em vigência no início de 2021. Com isso, pretende-se diminuir a emissão de gases proveniente do processo de fabricação do plástico a partir da utilização de combustíveis fósseis e a poluição das águas - evitando o agravamento da deposição nos oceanos. O problema é bastante conhecido na Indonésia considerado como o segundo lugar em extensão de plastic soup, sendo resultado de uma má gestão desses resíduos na Indonésia, (Colombijn; 2020). No entanto, em relatório, a Comissão Europeia (2018:3) destacou estudos que revelaram a acumulação de plásticos no Mediterrâneo em densidade comparável aos encontrados no Oceano Índico.

No Brasil, as políticas neoliberais têm sido implementadas quase como uma caricatura do modelo de estado-centauro (Wacquant, 2012) adotado pelos Estados Unidos - em que há a liberdade extrema no topo da pirâmide, ao mercado e às negociações, mas é extremamente penalizante na base social. Por isso, cabe ressaltar que os atritos observados no país nos últimos meses entre os três poderes, muitas vezes, limitados ao próprio executivo - opondo ministros e presidente - deixam um pouco aquém do que se entende por estado neoliberal, compreendido a partir de Harvey como aquele que "deve favorecer fortes direitos individuais à propriedade privada, ao regime de direito e às instituições de mercados de livre funcionamento e do livre comércio (2008:75)". Afinal, a figura da presidência persiste em diluir-se com a própria ideia de

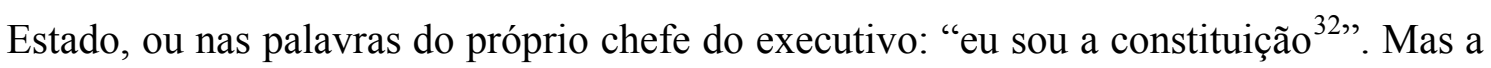
freak version à brasileira mantém-se muito fiel aos cortes nas políticas públicas voltadas ao bem-estar da população, à privatização de empresas públicas e à terceirização de serviços, à precarização das relações de trabalho, e, obviamente, ao transbordamento no paternalismo punitivo (Wacquant, 2012) na base da população.

A narrativa que aborda a formação em gestão comunitária de resíduos orgânicos e agricultura urbana pela Revolução do Baldinhos ilustra bem os efeitos causados pelo estado-centauro. Sobre a região, o Morro da Queimada/Mocotó, tem seu acesso pelo bairro José Mendes por uma rua asfaltada, larga, onde se aglomeram casas de alto padrão, espaçosas, com grandes janelas em que se pode contemplar o mar, as montanhas

\footnotetext{
${ }^{32}$ Em entrevista no portão do Palácio da Alvorada, o presidente Jair Bolsonaro justificou sua postura ao falar o que compreende por liberdade e democracia: "eu sou a Constituição". Para mais, ver: SOUZA, Josias. Bolsonaro, versão Luís 14: "A Constituição sou eu".

Disponível em: https://noticias.uol.com.br/colunas/josias-de-souza/2020/04/20/bolsonaro-em-versao-luis14-a-constituicaosou-eu.htm. Acesso em: 16 de agosto de 2020.
} 
continentais e a ponte Hercílio Luz - considerada uma das vistas mais desejadas da cidade. Os muros altos denunciam o recurso bastante particular aos lares das camadas médias altas brasileiras: a segregação entre classes (Caldeira, 2002). À medida que vamos subindo, a rua torna-se estreita e as pequenas casas surgem aglomeradas, num padrão de moradias - fruto da mesma política habitacional que reurbanizou a comunidade da Chico Mendes. A comunidade do morro do Mocotó, embora faça fronteira com a Queimada no topo, possui a principal via pelo bairro da Prainha, situado muito próximo ao centro de Florianópolis. No entanto, muitas casas só podem ser acessadas pelas escadarias.

Essa região tem o histórico de ocupação, revelando outro traço de segregação bastante entranhado no pensamento social brasileiro: o racial. Parte das/os moradoras/es tem origem quilombola ${ }^{33}$, existindo no Morro da Queimada um Núcleo de Educação Quilombola (NEQUI), na modalidade de Educação de Jovens Adultos (EJA). Situado mais próximo ao centro da cidade, o Morro do Mocotó possui uma população remanescente das desapropriações das/os moradoras/es de cortiços e de casebres que foram derrubados para as reforma urbanísticas ocorridas na cidade durante as primeiras décadas do século $\mathrm{XX}^{34}$. Segundo uma moradora septuagenária, o morro era bastante frequentado por "marinheiros" atraídos pelo samba e pelo mocotó. O prato deu origem ao nome do local (Gonçalves, 2015). Os "marinheiros", na verdade, correspondiam a homens pretos e pardos oriundos do Rio de Janeiro e de estados nordestinos que faziam parte do $5^{\circ}$ Distrito Naval. Essas pessoas tiveram grande importância na introdução de escolas de samba em Florianópolis, como nos mostra Natan Kremer (2019):

O $5^{\circ}$ Distrito Naval parece ter sido de grande importância por trazer à cidade,
como vimos, marinheiros cariocas e nordestinos que, como aponta o autor ${ }^{35}$,
instalaram- se no Morro do Mocotó, nas imediações do Centro de
Florianópolis. Neste momento, o samba enquanto gênero musical ganhou
espaço. [...] A composição das Escolas mostra a presença, então, de antigos
moradores de Florianópolis, junto a esses novos moradores que, como se
pode inferir a partir de Ramos (1997), são negros, e passam a residir no

${ }^{33} \mathrm{Na}$ edição do Caderno de Políticas de Educação Quilombola da Secretaria de Educação de Santa Catarina, o Morro da Queimada aparece como comunidade quilombola reconhecida pela Gerência Regional de Educação (GERED) e Coordenadoria Regional da Grande Florianópolis (COREF), porém, ainda aguardando análise técnica da Fundação Cultural Palmares (FCP)

${ }^{34}$ Como ocorrido em outras cidades do país, os cortiços localizados na área central de Florianópolis foram destruídos para dar lugar à avenidas. Sua população foi expulsa, indo procurar moradia nos morros da região, já que a área central concentrava a maior parte dos empregos. Ver: ARAUJO, Hermetes Reis. A invenção do litoral: reformas urbanas e reajustamento social em Florianópolis na Primeira República (Dissertação). Programa de Pós-Graduação em História da Pontifícia Universidade Católica de São Paulo, 1989.

${ }^{35}$ Kremer esá se referindo ao trabalho de Àtila Ramos: RAMOS, Átila Alcides. Carnaval da Ilha. Florianópolis: Papa Livro, 1997. 
mesmo espaço que os descendentes de escravizados, mesmo que ocupem posição dentro da estrutural estatal, por meio do $5^{\circ}$ Distrito Naval, ligado ao Porto [...] (Kremer, 2019: 86-87).

O autor reforça como a segregação racial fortemente presente na cidade foi responsável pela configuração atual da região do Maciço do Morro da Cruz. Beatrice Gonçalves (2015) nos aponta que esse padrão segregacionismo, já era comum na região no século XIX:

\begin{abstract}
Até o começo do século XX, o mar chegava próximo ao Morro e por conta disso, moravam na região muitos pescadores e marinheiros. A parte mais baixa do Morro e que estava próxima ao mar era conhecida como região da Toca, hoje chamada de Prainha, sendo que a região do Morro do Governo [hoje, Morro do Mocotó], concentrava-se do meio para o alto do Morro. [...], a Toca foi o primeiro lugar segregado de Desterro, no sentido de que era uma área, até então afastada do centro comercial, onde se concentrava um determinado perfil da população, o de marinheiros e de pescadores (Gonçalves, 2015: 26).
\end{abstract}

Ambos os morros, embora em áreas centrais, são considerados zonas da periferia urbana. Ao contrário do clássico conceito de Robert Park (1967), as periferias urbanas brasileiras não são assinaladas apenas pela distancia geográfica em relação ao centro, mas por uma distância simbólica. São consideradas locais de grande vulnerabilidade social, em que a fronteira é delimitada pelo acesso da população aos aparatos estatais, tornando-se um local de forte tensão política (Feltran, 2010). A presença do Estado é mais visível através das medidas de segurança pública adotadas, uma vez que as ações policiais nessas localidades são seguidas e extremamente violentas. A ação narrada na cena etnográfica é bastante ilustrativa: a ação truculenta da tropa de ações especiais da PM que adentrou na comunidade com armamento pesado, ameaçando moradores incluindo crianças que brincavam no local - e impedindo que qualquer pessoa ou veículo deixasse o local. Um tipo de ação que dificilmente veríamos em regiões onde predominam as camadas médias e altas.

\title{
Considerações Finais
}

A Antropologia Urbana possui uma larga tradição nos estudos sobre consumo material. Poderíamos listar uma grande quantidade de subáreas que exploraram essa temática, no entanto, para este item destaco três. A primeira delas corresponde à perspectiva de Arjun Appadurai (2008) que relaciona o consumo e a vida social das 
mercadorias ao processo de globalização nas últimas décadas do século XX. A segunda está simetricamente ligada a anterior, seguindo a linha dos estudos da cultura material, porém com foco no objeto. Destaco o trabalho de Daniel Miller (2013), em que o autor analisa a ampla categoria de "treco" (stuff) - o que conflui uma variedade coisas, tendo se eximido de qualquer definição ${ }^{36}$. Outra área que tem refletido sobre consumo consiste nos estudos sobre "resíduos sólidos" (waste), estágio final no processo de produção (Rial; Colombijn, 2016) - e que, entre nosso grupo de pesquisadores ${ }^{37}$, temos procurado definir como Antropologia do Lixo/Resíduos Sólidos. Mas como poderíamos pensar a negação, ou melhor, o rompimento sobre a relação social que temos com o “consumo de mercadorias", com os "trecos" e com os "resíduos"?

O significado por trás desse rompimento, nas diferentes frentes, inclui formas de resistências contra o neoliberalismo atuante em diferentes partes do mundo. Modelos que têm se mostrado insustentáveis e que levaram à adoção de um pacto global para a diminuição dos efeitos danosos ao planeta. São modelos de economias circulares e/ou solidárias que são filhas de seus contextos, traduzidos nas narrativas aqui expostas: a Tecnologia Social replicada pela Revolução dos Baldinhos que têm a preocupação com a geração e circulação de renda em locais onde o Estado encontra-se ausente - ou presente e em conflito direto com a comunidade através da força policial; a preocupação das camadas médias e altas em consumir produtos limpos - livres de resíduos, de agrotóxicos, que causem o mínimo de impacto ao meio ambiente - ou de buscar um estilo de vida que inclua menos material e mais afetos; ou jovens acadêmicos que doam parte de seu tempo em ações que mostram que o desperdício de alimento - inutilizados para a venda nos mercados - podem gerar refeições fartas e saudáveis, capazes de diminuir a fome de inúmeras pessoas.

Os Objetivos para o Desenvolvimento Sustentável da ONU trouxeram a problemática da desigualdade social para o debate, obrigando que países signatários incluíssem em suas agendas políticas públicas que acionem o bem-estar social. Obviamente que os efeitos são mais sentidos nas camadas mais baixas do sul global.

\footnotetext{
36 "Este livro fala da variedade de coisas que podemos chamar de treco, mas em parte alguma, aqui, você encontrará qualquer tentativa de definição do termo. A meta, antes, é apresentar minha própria perspectiva sobre o estudo da cultura material, um conjunto de pesquisas que se interessam principalmente por trecos. Cultura material não é mais bem-definida que treco" (Miller, 2013:7).

${ }^{37}$ Que compõem a rede criada pelos projetos "Economia circular: antropologias do lixo/resíduos sólidos e experiências inovadoras entre Holanda e Brasil", composto por pesquisadores de diferentes instituições: UFSC, UFRGS, UNILA, UFAM, UFPE e VU Amsterdam.
} 
Esta pesquisa procurou se encaixar dentro do que Sherry Ortner definiu por "antropologia da resistência", pois enfatiza ao mesmo tempo o estudo crítico da ordem atuante, a partir da 'crítica cultural', e novas visões políticas e econômicas alternativas a partir do estudo etnográfico de movimentos sociais" ${ }^{\text {"3 }}$. É dentro dessa perspectiva que se podem integrar os campos: como movimentos que contestam e sugerem reformas na ordem de consumo e de descarte de produtos, acentuados pelas políticas neoliberais adotadas nos respectivos países: Brasil, Portugal e Países Baixos. Compreendem-se os atores sociais diante de um panorama global em que se observa a tensão entre o fortalecimento da extrema direita de robusto posicionamento neoliberal, em contraste com a resistência de ambientalistas que alertam para a escassez de matérias-primas e para excesso no descarte de resíduos. Desse contexto, pululam movimentos em diversos setores relacionados à emergência de economias voltadas ao desenvolvimento sustentável - sendo estes, talvez a resistência que possua maior poder frente a esse estágio do capitalismo. Isso talvez só seja possível porque o impacto social causado pelos efeitos do Antropoceno ${ }^{39}$ atinge, de maneira diferenciada, todas as camadas sociais em todo o planeta.

\section{REFERÊNCIAS}

ABREU, Marcos José de. Gestão comunitária de resíduos orgânicos: o caso do projeto Revolução dos Baldinhos (PRB), capital social e agricultura urbana. 2013. Dissertação (Mestrado em Agroecossistemas). Universidade Federal de Santa Catarina, Florianópolis.

CHUA, L.; FAIR, H. Anthropocene. In: F. Stein, S. Lazar, M. Candea, H. Diemberger, J. Robbins, A. Sanchez \& R. Stasch (Eds). The Cambridge Encyclopedia of Anthropology. Cambridge: Cambridge University, 2019.

\footnotetext{
${ }^{38}$ ORTNER, Sherry. Dark anthropology and its Others. Hau: Journal of Ethnographic Theory 6 (1): 4773.

${ }^{39}$ CHUA, L.; FAIR, H. Anthropocene. In: F. Stein, S. Lazar, M. Candea, H. Diemberger, J. Robbins, A. Sanchez \& R. Stasch (Eds). The Cambridge Encyclopedia of Anthropology. Cambridge: Cambridge University, 2019. Disponível em: http://doi.org/10.29164/19anthro
} 
COLOMBIJN, Freek. Secrecy at the End of the Recycling Chain: The Recycling of Plastic Waste in Surabaya, Indonesia. Worldwide Waste: Journal of Interdisciplinary Studies, 3(1), 2020.

COLOMBIJN, Freek; RIAL, Carmen. Abordagens antropológicas dos resíduos sólidos em sociedades pós-industriais. RIAL, Carmen. O poder do lixo: abordagens antropológicas dos resíduos sólidos. Rio de Janeiro: Associação Brasileira de Antropologia, 2016.

COMISSÃO EUROPEIA. Comunicação da Comissão ao Parlamento Europeu, ao Conselho, ao Comité Económico e Social Europeu e ao Comité das regiões: uma estratégia europeia para os plásticos na Economia Circular. Estrasburgo, 2018. Disponível em: https://eur-lex.europa.eu/resource.html?uri=cellar:2df5d1d2-fac7-11e7b8f5-01aa75ed71a1.0020.02/DOC_1\&format=PDF. Acesso em: 22 de agosto de 2020.

CRUZ, Cintia A. BITTENCOURT, Paula T. Cartilha de formação: gestão comunitária de resíduos orgânicos e agricultura urbana. Florianópolis: Instituto ÇaraKura, 2019.

FELTRAN, Gabriel. Periferias, direito e diferença: notas de uma etnografia urbana. Revista de Antropologia, São Paulo, USP, 53 (2), 2010.

GONÇALVES, Beatrice C. O. O ensopado que alimenta, identifica e dá nome ao Morro do Mocotó (Dissertação). Florianópolis: Programa de Pós Graduação em Antropologia Social (PPGAS/UFSC), 2015.

HARVEY, David. O neoliberalismo: história e implicações. São Paulo: Edições Loyola, 2008.

KREMER, Natan S. Fragmentos de uma educação para o moderno na Florianópolis de Salim Miguel (Monografia). Trabalho de Conclusão de Licenciatura para a obtenção do grau de Licenciado em Ciências Sociais. Florianópolis: Universidade Federal de Santa Catarina, 2019.

MILLER, Daniel. Trecos, troços e coisas: estudos antropológicos sobre a cultura material. Rio de Janeiro: Zahar, 2013.

MURPHY, Erin. Less is more work: a governmentality analysis of authenticity within minimalism discourse. Tese (Doutorado em Sociologia). Carleton University: Ottawa, Ontario, 2018.

ORGANIZAÇÃO DAS NAÇÕES UNIDAS. Transformando o nosso planeta: a agenda 2030 para um desenvolvimento sustentável. Disponível em: 
https://nacoesunidas.org/wp-content/uploads/2015/10/agenda2030-pt-br.pdf. Acesso em 16 de agosto de 2020 .

ORTNER, Sherry. Dark anthropology and its Others. Hau: Journal of Ethnographic Theory 6 (1): 47-73.

ORTNER, Sherry. On neoliberalism. Anthropology of this century. Londres: Issue.1; Maio, 2011. Disponível em: http://aotcpress.com/articles/neoliberalism/. Acesso em: 12 de junho de 2020 .

PARK, Robert. E. The urban community as a spatial pattern and a moral order in $O n$ social control and collective behavior. Chicago/London: The University of Chicago Press, 1967, p. 55-68.

SANTA CATARINA; GOVERNO DO ESTADO; SECRETARIA DE ESTADO DA EDUCAÇÃO. Política de educação escolar quilombola. Estado de Santa Catarina, Secretaria de Estado da Educação. Florianópolis: Secretaria de Estado da Educação, 2018.

SCHNEIDER, Kamila Guimarães. A revolução está no prato: do global ao local no Movimento Slow Food. Dissertação (Mestrado em Antropologia Social), Universidade Federal de Santa Catarina, Florianópolis, 2015. 173 pp.

SINGER, Paul. Introdução à economia solidária. São Paulo: Fundação Perseu Abrama, 2002.

VIANA, Nildo. Breve história do neoliberalismo. Revista Enfrentamento, n. 05, jul./dez. 2008, p. 4-10.

WACQUANT, Loïc. Três etapas para uma antropologia histórica do Neoliberalismo realmente existente. Caderno CRH, v. 25, n. 66, Set./Dez. 2012 p. 505-518.

Recebido: $02 / 09 / 2020$

Aprovado: $08 / 12 / 2020$ 